International Journal of Agriculture, Environment and Bioresearch

Vol. 5, No. 03; 2020

ISSN: $2456-8643$

\title{
PRODUCTION OF BASELINE RICE AND LOCAL DEVELOPMENT IN THE COMMUNE OF ADJA-OUERE IN SOUTH-BENIN
}

\author{
Pascal GBENOU \\ Research Unit in Plant Biotechnology, Crop Protection and Seed Sciences; Plant, Horticultural and Forest Sciences \\ Laboratory; School of Plant and Seed Management and Production (EGPVS); \\ National University of Agriculture (UNA) BP 43 Kétou Bénin \\ Email : gbenoup@gmail.com
}

https://doi.org/10.35410/IJAEB.2020.5506

\begin{abstract}
One of the national agricultural priorities is rice cultivation which is more and more attracting Beninese government attention and private economic operators, at the same time as it is a driving force for structuring the rural environment. The present study is interested in the production of lowland rice in relation to development in the municipality of Adja-Ouèrè in Benin. The data used here are inter alia the agricultural statistics relating to the evolution of the area sown, the yields and the production of rice, the climatological data (rains and temperatures on a monthly and / or annual scale) of the agro-agricultural station. Pobè climatology, socio-economic information and on rice production systems collected from stakeholders during fieldwork. These different data are subject to processing using the descriptive statistics method. Likewise, the Economic Profitability Analysis of rice production was made. An analysis of the results shows that the municipality of Adja-Ouèrè has enormous physical potential for the production of lowland rice. The yield of lowland rice has changed in the municipality of Adja-Ouèrè in recent years, going from $2,500 \mathrm{~kg} /$ ha in 2009 to $7,500 \mathrm{~kg} /$ ha in 2017 , i.e. an increase in productivity of $158.52 \%$. In fact, the production system generates a gross margin of CFAF 303,250 / ha. The average return on capital is therefore around $161 \%$. Thus, 100 francs invested in the production of rice in the commune generate an income of 161 francs for a production cycle of five months. Rice production in the municipality of Adja-Ouèrè therefore appears profitable. But for the sustainability of these achievements a reorganization of the rice sector is essential
\end{abstract}

Keywords: Municipality of Adja-Ouèrè, Rice production; economic profitability, local development.

\section{INTRODUCTION}

Rice is the most important food crop and the most cultivated cereal in the world after wheat (Raemaekers, 2001). With a production of 600 million tonnes of paddy rice in 2005 (Trébuil and Hossain, 2004; Jeanguyot and Ahmadi, 2005; Mendez, 2006), for many countries rice has a double economic and social stake in terms of its marketing, food security and poverty alleviation. However, there are many possibilities for increasing rice production, including wetlands or shallows. 
The Beninese State, through the Strategic Recovery Plan for the Agricultural Sector (PSRSA), has made rice a priority sector with the objectives of increasing areas and yields leading to a high consumption of locally produced rice. Similarly, thanks to the Emergency Food Security Support Program (PUASA), subsidies and facilitation of access to the means of production have increased the enthusiasm of producers (FoReVA, 2013). Considered in the past as a luxury food, therefore consumed only during festivals and special events, rice has gradually entered the eating habits in Benin (CCR, 2004). Indeed, according to Verlinden and Soule (2003), Benin has a potential of more than 322,000 ha of cultivable land, including 205,000 ha of shallows and 117,000 ha of floodplains. Barely $10 \%$ of this potential is currently exploited for rice cultivation (SNDRB, 2011). With this potential, Benin could become self-sufficient in rice and even export the surpluses of its rice production. On the strength of this observation and as this study proposes, it would be interesting to take stock of the situation on a local scale in order to draw conclusions on a national scale. This is what justifies the choice of this research work which relates to the production of basalt rice in relation to local development in the commune of AdjaOuèré in South Benin.

\subsection{Study environment}

The study environment is located between $6^{\circ} 36^{\prime}$ 'and $7^{\circ} 06^{\prime}$ 'north latitude and $2^{\circ} 30$ ' and $3{ }^{\circ}$ $00^{\prime}$ east longitude. Located in the south-east of Benin and in the center of the Plateau department. It is bounded to the north by the municipalities of Kétou and Zagnanado; to the south by the commune of Sakété; to the east by the municipality of Pobè and the Federal Republic of Nigeria; to the west by the municipalities of Ouinhi and Bonou. It has an area of 550 $\mathrm{km}^{2}$ which represents $11.6 \%$ of the area of the Plateau department and $0.48 \%$ of that of Benin (Figure 1). 


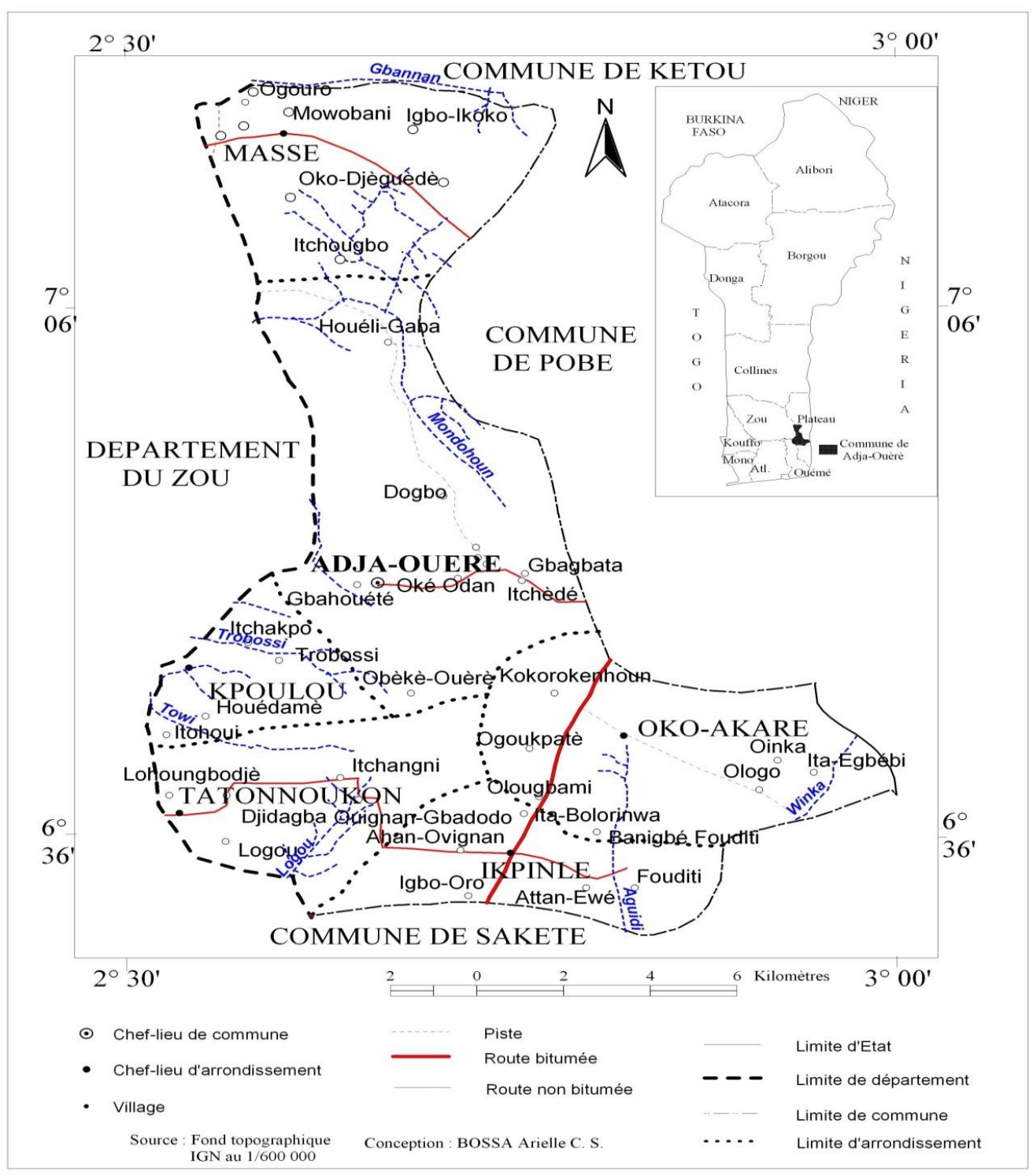

Figure 1: Geographic location of the Municipality of Adja-Ouèrè

The municipality of Adja-Ouèrè enjoys a subequatorial climate (Figure 2), the long rainy season extends from mid-March to July, the short rainy season, from mid-September to October; the long dry season from November to March and a second short dry season from August to midSeptember. This situation thus offers the possibility of two cropping cycles 


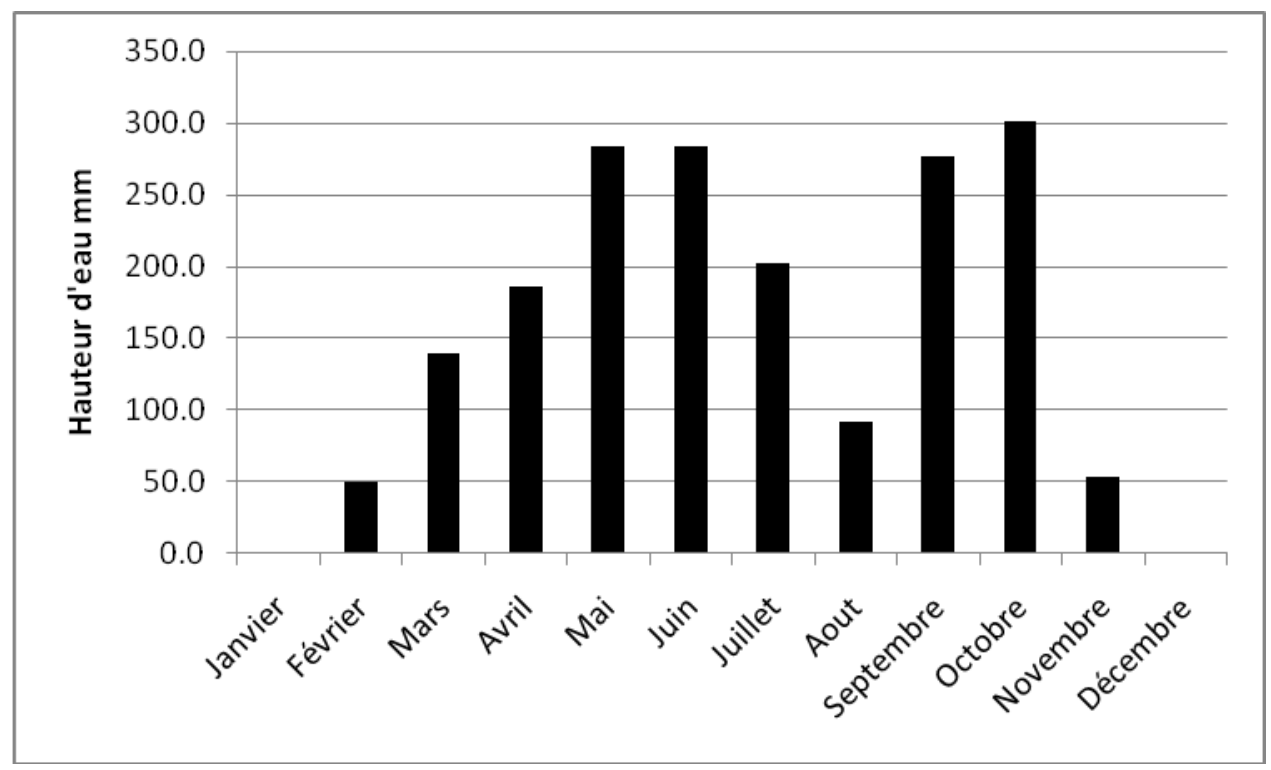

Figure 2: Average level of rainfall in the municipality of Adja-Ouèrè

Source: Météo-Bénin, 2018

The peak rainfall is between May and June whose rainfall is between $283.4 \mathrm{~mm}$ and $283.7 \mathrm{~mm}$ while the average rainfall is $1152.4 \mathrm{~mm}$ throughout the town. However, this rainfall varies according to the years between 710.7 and $1613.9 \mathrm{~mm}$. These rainfall parameters seem to respond well to the cultivation of rice which requires a rainfall of between $800 \mathrm{~mm}$ and $1000 \mathrm{~mm}$ for a vegetative cycle of 4 to 5 months (Raemakers et al, 2001). Temperatures fluctuate between $25^{\circ}$ $\mathrm{C}$ and $33{ }^{\circ} \mathrm{C}$ throughout the year with highs ranging from $33^{\circ} \mathrm{C}$ to $32{ }^{\circ} \mathrm{C}$ on the one hand, and minima between $25^{\circ} \mathrm{C}$ and $26^{\circ} \mathrm{C}$ on the other. These thermal values fit well within the acceptable limits for the production of lowland rice. Two main types of soil are observed, these include: ferralitic soils in the plateau area; clay-humic soils commonly called "Vertisols" resulting from the degradation of limestone rocks in the depression area (Adja-Ouèrè town hall). It is on these types that the shallows that are the subject of this study are based. The hydrographic network is scarce. It consists of a few streams estimated at around $17 \mathrm{~km}$, the most important of which are Iguidi, Gba, Idogbo and significant reservoirs during the rainy season in clay areas. We note the existence of artesian wells gushing in the arrondissement of Massè.

\section{METHODOLOGICAL APPROACH}

The methodological approach used in this research work revolves around the data collected, the techniques and tools for processing, analyzing and interpreting the results.

\subsection{Nature and source of the data used}

The data used in this study are both qualitative and quantitative, these include:

Agricultural statistics relating to the development of the area sown, the yields and the production of rice which were collected in the SCDA of the Municipality of Adja-Ouèrè and the MAEP; 
climatological data (rains and temperatures on a monthly and / or annual scale) from the agroclimatological station of Pobèqui are collected at Météo-Bénin over the period from 1971 to 2015;

\section{Demographic data at INSAE}

Socio-economic and agronomic information relating to rice farming systems collected from stakeholders.

\section{Data processing and results analysis}

The study of the monthly rhythms of rain depths was carried out from the determination of the arithmetic mean which is presented as follows: This value is considered as a normal mean. Thus the graphs produced, made it possible, in terms of agricultural data, to better understand: The evolution of production in (tonnes), areas sown in (hectare) and annual yields in ( $\mathrm{kg} / \mathrm{ha}$ ), targeted crops .

The population of the study environment by 2025 was determined using the following formula:

$\mathrm{Pt}=\mathrm{P} 0(1+\mathrm{r}) \mathrm{t}$ with

Po $=$ Population at the time of departure considered, ie in 2013

$r=$ Population growth rate

$\mathrm{t}=$ time between 2013 and the year considered.

The economic profitability analysis of rice production was made from a standard operating account of rice production in the commune near the field work. This table took into account operating costs, materials, inputs and others.

\section{RESULTS AND DISCUSSIONS}

The results presented revolve around the mode of access to land, production systems and finally the economic aspects of production.

\subsection{Rice cultivation system}

The farming systems, the technical itineraries and the varieties of lowland rice cultivated in the Municipality of Adja-Ouèrè are discussed here.

\subsubsection{Mode of land acquisition in the Municipality of Adja-Ouèrè}

Land is the primary factor of production in agriculture. In the study environment, several modes of access to land are enumerated as shown in Figure 3. 


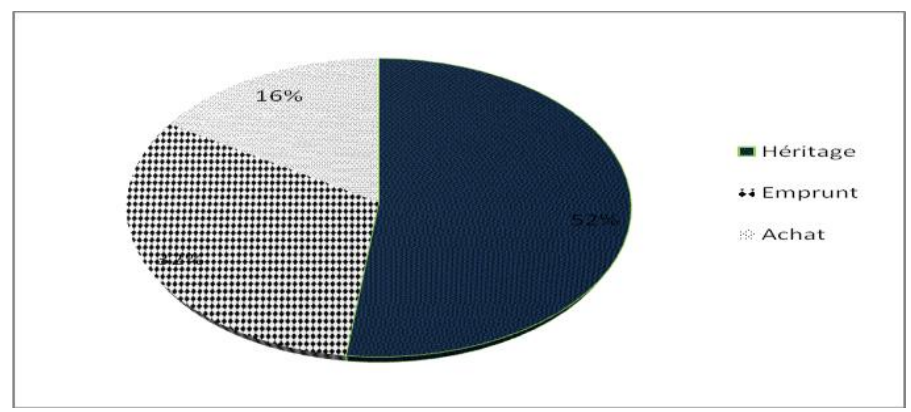

Figure 3: Access to land in the municipality of Adja-Ouèrè

Source: Field survey, 2018

The method of promotion that predominates in the groups visited is the heritage for $52 \%$ of the respondents. It is followed by the $32 \%$ loan and the $16 \%$ purchase. The land is borrowed from the "fons" by the "hollis" who benefit from the after-effect of the use of mineral fertilizers in the production of certified rice seeds for the cultivation of maize during the long rainy season. All these social characteristics are the basis of the economic performances observed in the production of rice in the lowlands in the Adja-Ouèrè commune. The land being acquired, the farming operations can be done if there are no other major constraints.

\subsubsection{Preliminary works}

\section{Development of the production site}

For the installation of a new production perimeter or a new plot, this operation is essential. Two types of development are possible: basic development and final development. Temporary management is the type of management practiced on the rice production sites of the municipality of Adja-Ouèrè. It consists of 05 essential operations: clearing, stump removal, flat plowing, delimitation of traps and formation of bunds. The arrangement is very important for the production of lowland rice because it contributes to the control of water in the rice perimeters.

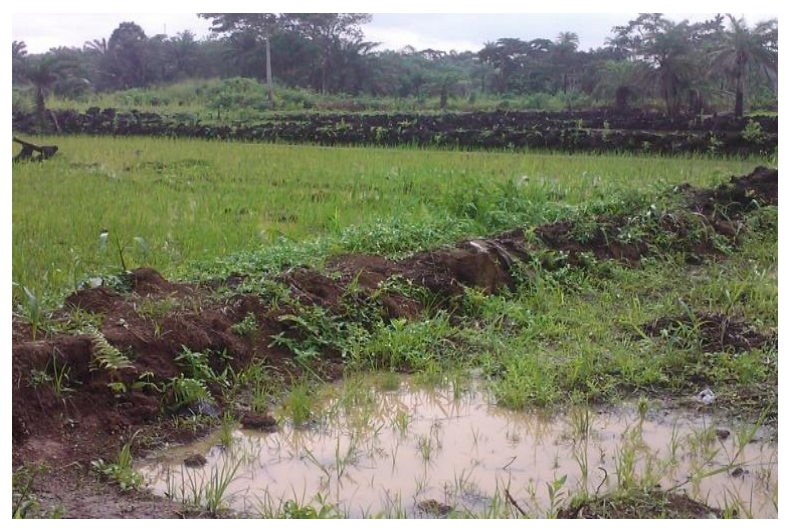

Photo 1: Type of basic development in the Municipality of Adja-Ouèrè

Shooting: BOSSA A., 2014 


\section{Weeding}

This operation is necessary for sites or plots already developed at the start of each campaign. For undeveloped sites or plots, this operation is taken into account by the development. It generally takes place between May and June and is carried out with a machete or by herbicidage. About $48 \%$ of the producers interviewed herbicide for this operation using total herbicides. After clearing, the herbs are left in place forming a thick carpet (mulch). This practice prevents the recovery of weeds from the roots. In addition, it protects the soil from the weather. According to the producers, this phase would allow the recycling of nutrients in the soil. Two to three weeks after clearing, the rest of the herbs are picked up and placed on the bunds of traps or used to form the bunds of some traps that do not have them.

\section{Stump}

It is the action of clearing a ground of the stumps remaining in the ground after the felling of trees.

\section{Plowing flat}

It is an operation which allows the burial of weeds and the preparation of the transplanting bed. This operation can be manual or mechanical. At all rice production sites in the commune, this operation is manual and consists of turning the strip of surface soil using the daba to a depth of about $15 \mathrm{~cm}$. For undeveloped sites or plots, this operation is also taken into account by the development and is mechanical if the development is carried out by a support organization. The type of development taking into account mechanical plowing is carried out on approximately $15 \%$ of the total area sown on rice production sites. This type of plowing requires an additional operation which is leveling which consists in preparing the plot to give good gravity to the rainwater to pass over the entire plot.

\section{Delimitation of lockers}

It is the act of circumscribing within clearly defined limits of the lockers.

\section{Preparation of bunds}

A levee to contain water in order to avoid its runoff.

\section{Choice of variety}

Basic seeds are supplied to multipliers by the National Institute for Agricultural Research in Benin (INRAB) and the cooperatives obtain them through the Rural Development Support Program (PADER) or the National Society for the Agricultural Promotion (SONAPRA). The multiplied varieties are determined by these programs according to the agronomic and organoleptic characteristics of the latter as well as the needs expressed by the producers of rice for consumption. The varieties currently multiplied in the commune are IR 841, NERICA L20 and BL19 which are all varieties of lowland rice. The varieties IR841 and BL19 are very productive line varieties with potential yields of 8 to $10 \mathrm{t} / \mathrm{ha}$. The NERICA-L20 variety is a 
hybrid resulting from the interspecific crossing between the African rice Oryza glaberrima and the Asian rice Oryza sativa. It is an early variety, very productive, more resistant to African diseases and drought. Under optimal conditions, NERICA-L20 has a yield of around $10 \mathrm{t} / \mathrm{ha}$ (FAO, 2010).

\subsubsection{Cultivation techniques for rice production}

Among the cultivation techniques, we can note:

\section{Nursery}

The establishment of the nursery is carried out on a small made board of approximately $1 \mathrm{~m}$ by 2 $\mathrm{m}$. This board is cleaned, muddy with a low water layer or without a water layer. After making the boards, the producers spread the seeds in bulk followed by a covering with fine earth coming from an area without mud, generally the land of the concertions. The board is then protected with palm branches and watered if there is no water. It takes the nursery of one (1) $\mathrm{kg}$ of basic seed to transplant two (2) traps, an area of $800 \mathrm{~m} 2$. The theoretical duration before transplanting is 2 to 3 weeks, but producers go up to one (1) month before transplanting. The seeds used for the establishment of the nursery are seeds which have been previously prepared. The seeds are soaked by the producers in water for 48 hours and then stored under cover of tarpaulins or in a bag for 48 hours to 72 hours, after the water has been removed. It is a practice that allows the dormancy of seeds to be lifted. They are then placed in the nursery as soon as the signs of pregermination appear.

\section{Transplanting rice}

It consists of transplanting the seedlings from the nursery into the previously plowed and planed traps. It is done in line with a line to one plant per pocket. The spacing adopted is generally $25 \mathrm{~m}$ by $25 \mathrm{~m}$ or $25 \mathrm{~m}$ by $30 \mathrm{~m}$. It theoretically intervenes 15 days after the installation of the nursery and can last a week. But the delay in plowing considerably influences the transplanting period. As a result, some rice seedlings are transplanted after more than 30 days in the nursery.

\section{Soil fertilization}

It is an operation which consists in providing plants with the nutrients they need to express their yield potential. To maintain soil fertility, it is important to use mineral fertilizers such as NPK and Urea in rice production. Mineral fertilization is a requirement of the technological package of seed production. NPK is applied as background fertilizer for all varieties and is applied on the fly. The recommended rate is $150-200 \mathrm{~kg} / \mathrm{ha}$. Urea, on the other hand, is applied as a cover fertilizer for about $11 / 2$ months after transplanting with a rate of 75 to $100 \mathrm{~kg} / \mathrm{ha}$. It emerges from the results of our surveys that on the sites, organic fertilization is ensured by plant debris and mineral fertilization by urea (46\% nitrogen) and NPK (10-20-20 or 15-20- 15). The adopted dose is $100 \mathrm{~kg}$ of NPK and $50 \mathrm{~kg}$ of urea per hectare; i.e. $4 \mathrm{~kg}$ of NPK and $2 \mathrm{~kg}$ of urea per 400 $\mathrm{m} 2$ bin. $60 \%$ of producers split the compound fertilizer at the rate of $50 \mathrm{~kg} / \mathrm{ha}$ of NPK before

transplanting and the rest 15 to 30 days after transplanting, while the other $40 \%$ spread every 100 $\mathrm{kg}$ per hectare before transplanting. Urea is brought 45 to 60 days after transplanting; that is to 
say at the run when the need for rice in nutrients is high, especially in nitrogen to fill the grains. These doses sometimes vary depending on the level of fertility of the plot and the growing environment (weeds, plant vigor or not, yellowing of plants, etc.). Spreading is done on the fly. Some producers sometimes use liquid fertilizer from Nigeria in place of urea at a dose of 1L / ha which is diluted in water.

\section{Weed management}

The rapid growth of the adventitious flora due to poor soil preparation and the small size of the rice seedlings, during the first weeks after transplanting, make them very quickly dominated and suffocated by weeds. For all multipliers and producers of rice for consumption, it is the most time-consuming and labor-intensive operation. An invasion of seed plots by weeds can lead to downgrading of production. Thus, producers seek to permanently keep their plot clean by regular weeding. To do this, all of the producers interviewed use herbicides for the first weeding. Herbicide is usually done 15 to 25 days after sowing. It is followed by one or two manual weeds to remove weeds on which herbicides have had little effect. The treatment is done on the entire surface using a manual pressure knapsack sprayer, with a capacity of 16 liters. No protective measures are taken by producers during treatment. The recommended dose for all the herbicides used is known to producers, however $42 \%$ of producers of certified rice seeds overdose. They argue that the higher the dose, the more they rate the effectiveness of the herbicides. This practice has effects on rice plants, the most important of which is burning the leaves and therefore slowing growth. Photos 4 and 5 show the scars from overdose of herbicides on rice leaves

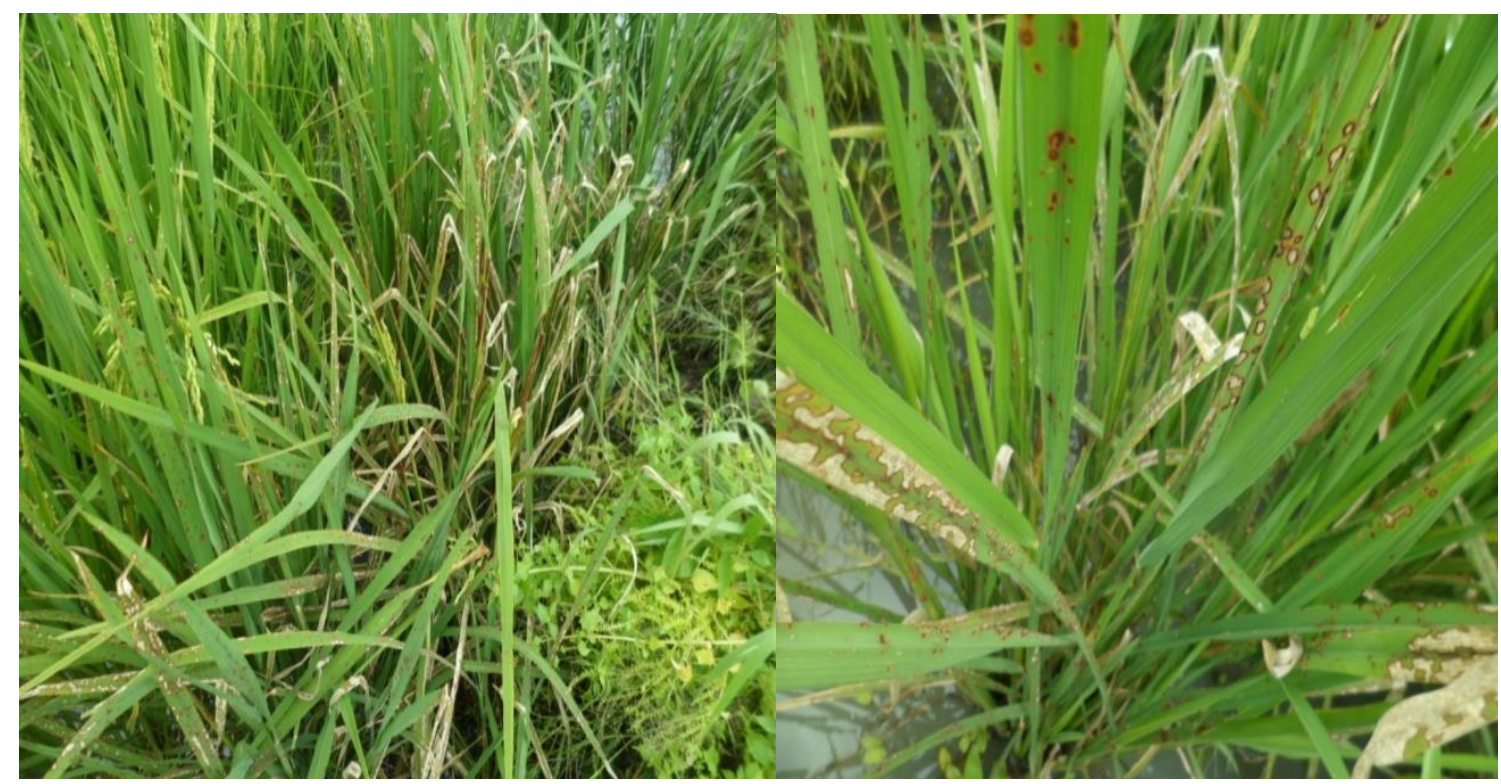

Plate 1: Scars from overdose of herbicides on rice leaves in the study environment

Shooting: BOSSA A., 2014

Pest / disease management 
From the nursery to storage, there are many pests that attack rice and affect both the quantity and the quality of the rice produced. As for diseases, they are few in rice cultivation. However, their attack also damages the seed produced. To fight against these pests or diseases, multipliers use various methods.

\subsection{Rice supply situation in the commune}

\subsubsection{Evolution of rice production in the Commune}

The SCDA statistics provide an idea of the level of agricultural production in the various localities of the Commune. These statistics made it possible to study the evolution of rice production between 2009 and 2017, as shown in Figure 4.

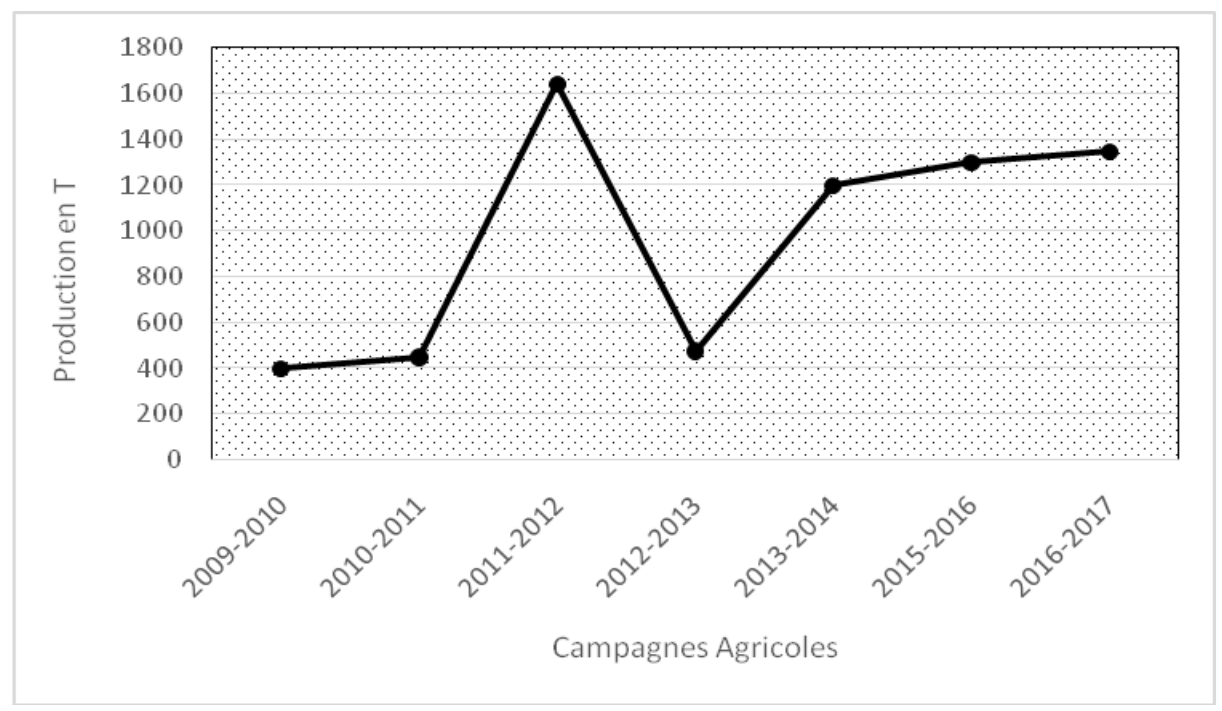

Figure 4: Evolution of rice production in Adja-Ouèrè from 2009 to 2017

Source: SCDA Adja-Ouèrè, and data from CCR-B

Analysis of the figure shows that rice production in the commune fluctuated from 2009 to 2017 with an average annual rate of 695 tonnes. The year 2011-2012 remains the year in which production reached its peak with a maximum annual rate of 1643 tonnes compared to 450 tonnes for 2010-2011. This good performance observed in 2011-2012 would be due to the strengthening of the SCDA staff during this period. On the other hand, 2010-2011 is the year when the flood hit the most in the commune.

\subsubsection{Evolution of the yield of rice cultivation in the commune}

Figure 5. shows the evolution of rice yields in the commune of Adja-Ouèrè from 2009 to 2017. 


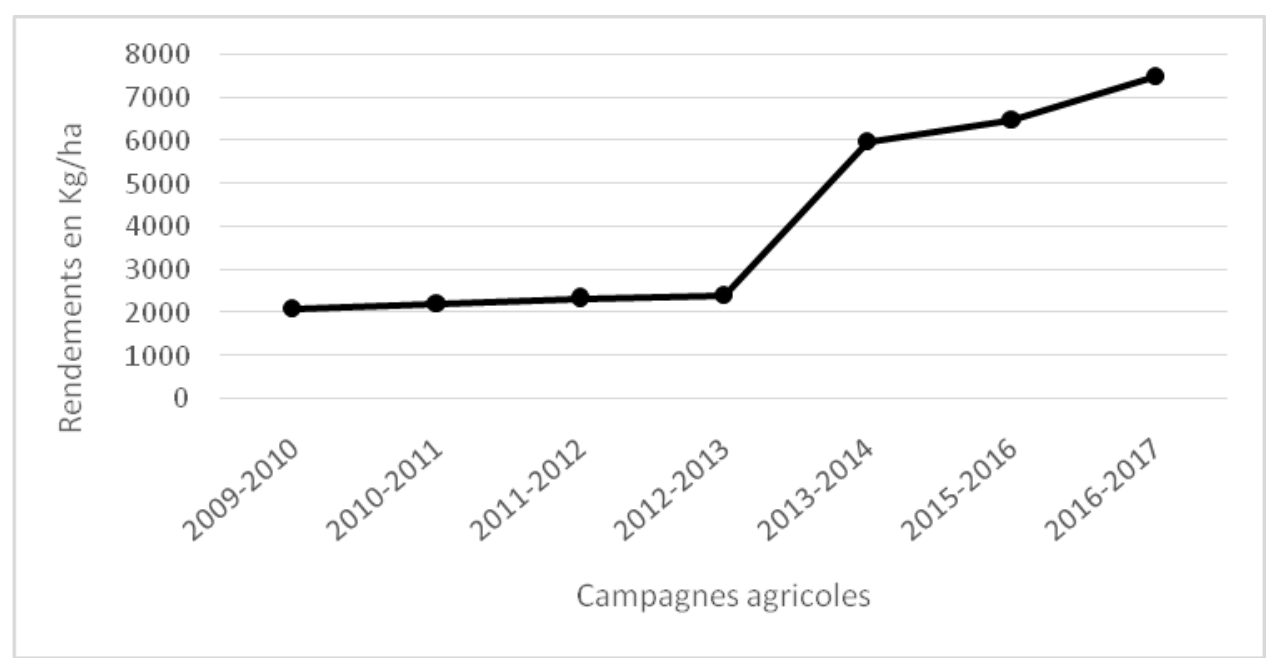

Figure 5: Evolution of rice production in Adja-Ouèrè from 2009 to 2017

Source: SCDA Adja-Ouèrè, and data from CCR-B

\subsection{Economic profitability analysis of rice production}

Field surveys of the various actors in the rice production chain as well as resource persons in the field made it possible to draw up the operating account in the Municipality of Adja-Ouèrè as shown in Table I.

Table I: Typical operating accounts for rice production in the commune of Adja-Ouèrè

\begin{tabular}{|c|c|c|}
\hline Wording & $\begin{array}{c}\text { Amount FCFA / } \\
\text { Canteen }\end{array}$ & Surface (ha) \\
\hline Operating costs & 1200 & 30000 \\
\hline Drain maintenance & 4000 & 100000 \\
\hline Weeding & 1500 & 37500 \\
\hline Grass picking & 1200 & 30000 \\
\hline Nursery & 1500 & 37500 \\
\hline Transplanting & 1000 & 50000 \\
\hline Sarclage & 400 & 10000 \\
\hline Spreading & 500 & 25000 \\
\hline Avian hunting & 1000 & \\
\hline Harvesting and bunching & & \\
\hline
\end{tabular}




\begin{tabular}{|c|c|c|}
\hline Threshing & 1000 & 25000 \\
\hline Winnowing and drying & 1500 & 37500 \\
\hline Bagging & 500 & 12500 \\
\hline Store transport & 600 & 15000 \\
\hline Sub total operations & & 422500 \\
\hline \multicolumn{3}{|l|}{ Inputs and equipment } \\
\hline Seeds & 110 & 2750 \\
\hline Fertilizer & 1680 & 42000 \\
\hline Fuel (motor pumps) & 400 & 10000 \\
\hline Bags (300f / bag) & 700 & 17500 \\
\hline $\begin{array}{c}\text { Sub-total of inputs and } \\
\text { equipment }\end{array}$ & & 72250 \\
\hline Production cost & & 494750 \\
\hline Products & & 798000 \\
\hline \multicolumn{3}{|l|}{ Yield (3.5 tonnes / ha) } \\
\hline \multicolumn{3}{|l|}{ Unit price (228fcfa / kg) } \\
\hline Marge brute & & 303250 \\
\hline Percentage & & 61,29 \\
\hline Percentage & & 161,29 \\
\hline
\end{tabular}

Source: Field data, 2016

Analysis of the table shows that family labor was counted there in the same way as salaried labor at the rate of 1,500 FCFA / man-day. Rice production in the commune of Adja-Ouèrè therefore appears profitable. In fact, the production system generates a gross margin of CFAF 303,250 / ha. The average return on capital is therefore around $161 \%$. Thus, 100 francs invested in the production of rice in the commune generate an income of 161 francs for a production cycle of five months. Rice production is therefore financially attractive. It should be noted that there is a strong potential for improving profitability through improved yield. Indeed, some producers reach around $5 \mathrm{t} /$ ha of paddy in the town. Thus, in view of the results obtained in this study, rice production deserves special attention from public authorities, development partners and also local authorities because it can not only help women and young people in increasing their income but be seen in the coming years as a job-providing sector. 
Vol. 5, No. 03; 2020

ISSN: $2456-8643$

\section{CONCLUSION AND RECOMMENDATION}

The commune of Adja-Ouèrè has enormous physical potential for the production of lowland rice. Even if this is not exactly the case in terms of production, yields have experienced progressive dynamics in recent years. The latter is linked to the presence of a young workforce, the monitoring of technical production routes and the gradual mechanization of certain activities. However, difficulties persist and manifest themselves in terms of the inorganization of the actors, the lack of public interest, ineffective production techniques. The rice sector is therefore in the embryonic stage and for this sector to develop, it is necessary to secure supply in order to encourage producers.

In view of the various evils which hinder the development of this sector, several actions will have to be undertaken, not only by the State, but also by the municipal authorities and the various actors intervening in the sector in Benin in general and in the commune of Adja-Ouèrè in particular. The Territorial Agency for Agricultural Development should place much more emphasis on advice relating to compliance with row sowing, the spreading of fertilizers in a closed line and the proper application of herbicides by rice farmers to raise the level of yield.

\section{REFERENCES}

Adégbola P. Y., Sodjinou E., 2003b. Analysis of the rice sector in Benin. Final report. PAPA / INRAB and PADSA. February 2003

Alohoun E., 2013. Analysis of the production system of certified rice seeds in the shallows of the Municipality of Adja-Ouèrè. Memory of Professional License 88 p

Baudry B. (1995). A new microeconomics: saving transaction costs. In Cahiers français de l'economie, ${ }^{\circ}{ }^{\circ} 272$. Pp 12-20.

DPQC, 2011. Collection of general and specific technical regulations approved for the production and marketing of seeds and plants in the Republic of Benin, Volume II, Cotonou, Benin.

FAO, 2011. Seed Systems .http / www. fao.org/agriculture/crops. Accessed on 10/23/2012.

IFDC, 2007. Diagnostic analysis and perspective of the rice sector in the Ouémé-Bénin valley, 58 pages.

INSAE Accounts. 2006-2007 Nationals

MAEP, 2010. Technical regulations for the production, quality control, certification and packaging of rice seeds. Cotonou, Benin, 25p.

MAEP, 2010. Agricultural Sector Recovery Strategic Plan (PSRSA). Cotonou, Benin, 108p.

MAEP, 2011. National Strategy for the Development of Rice Cultivation in Benin, (SNDRB). Cotonou, Benin, 30p. 
Rice Farmers' Concertation Committee. "Benin Rice Farmers Forum. Summary of work and recommendations", May 2004. - 9 p.

Raemaekers R.H. (2001): Agriculture in tropical Africa. Ed. Ministry of Foreign Affairs, Foreign Trade and International Cooperation, Directorate General for International Cooperation (DGCI) Brussels. pp 39-43.

Trébuil G, Hossain M. (2004): Rice: ecological and economic issues. Belin, Paris, 265p.

Jeanguyot M., Ahmadi N. (2005): Grain of rice, grain of life. Magellan, Paris, 129 p.

Mendez Del Villar, P. (2006): Territorial dynamics of the cultivation of rain-fed rice in the central region of Brazil. In Cyclope 2006: world markets. Paris, pp 223-227.

FoReVA, 2013: Final protocol report on IR 841 rice production techniques in the shallows of the Commune of Glazoué - Department of Hills (Center Benin). 42 p. 